\title{
A Nation within a Nation: English Education as a Tool of Divide and Rule Policy in Colonial India
}

\author{
Thakurdas Jana ${ }^{1} \&$ Sandip Sarkar ${ }^{2}$ \\ 'State Aided College Teacher, Post-Graduate Department of English, Bhatter College, \\ Dantan, West Bengal, India. E-mail: thakurdasogo1@gmail.com \\ ${ }^{2}$ Assistant Professor, Department of Humanities and Social Science, NIT, Raipur, India. \\ E-mail: sandipsarkar7@gmail.com
}

\begin{abstract}
Famous Irish political scientist and historian, Benedict Anderson, in his book, Imagined Communities: Reflections on the Origin and Spread of Nationalism has described nations as imagined communities. Stephen May, the British novelist, playwright, and TV writer, has viewed that language is used as a political tool to strengthen the imagined community of a nation-state. Eventually, many countries have been named after the language predominantly used in a particular country. But during the colonial expansion that the linguistic identity of a colonised nation like India and its people has been transformed in different ways. With the English Education Act, 1835 Lord Bentinck defeated the Orientalists and promoted English education in India. Consequently, different missionaries like Joshua Marshman, William Carey, William Ward, and Alexander Duff, who principally used English education to preach Christianity among the Indians, and British officials like Charles Grant, Lord Macaulay, William Hazlitt, and also some higher-class Indians like Raja Rammohan Roy, Keshab Chandra Sen, Bankim Chandra Chattopadhyay supported the Anglicist view and tried to spread the English education in India. Different English schools like Dharmatala Academy were built and in the curriculum of different universities, the writings of different English authors like Francis Bacon, William Shakespeare, John Milton, Joseph Addison, Alexander Pope were included. Many higher-class Indians became more interested in English study losing their interest in vernacular education. Vijay Agnew in her autobiography, Where I Come From, and Madhu Kishor in her article "The Dominance of Angreziyat in Our Education" have accused English education of making them unaware and ignorant of the Indian culture and writings. In this way, the higher-class English educated Indians have created one English nation within the Hindustan. Even the translation of different Indian classical texts into English like Sir William Jone's translation of Abhjnanasakuntalam in 1789 and Sir Charles Wilkins' translation of Bhagabadgita in 1784 has also paved the way for forming a different identity. In this context, the present paper aims to show how the different tools for spreading the English language divided the nation into two, supporting the divide and rule policy of the British, which is still effective in the so-called united, equal, and democratic India.
\end{abstract}

Keywords: nation, division, colonialism, English education, India.

In the very introduction of his book entitled Imagined Communities: Reflections on the Origin and Spread of Nationalism, Benedict Anderson defines the nation in an 'anthropological spirit' as "... an imagined political community- an imagined as both inherently limited and sovereign" (Anderson 2015: 6). Language plays a crucial role in forming an imagined community and it is found that most of the bordered lands, it may be countries or states in India, have been terms of the language popularly used in the lands. Stephen May, the British novelist, playwright and TV writer, in his book entitled Language and minority rights: Ethnicity, nationalism, and the politics of language (2008) has viewed that language is used as a political tool to strengthen the imagined community of a nation-state (May 2008). Gayatri Chakravarty Spivak in her interview with Judith Butler comments that "language becomes one way of asserting criteria control over

(C) AesthetixMS 2021. This Open Access article is published under a Creative Commons Attribution Non-Commercial 4.o International License (http://creativecommons.org/licenses/by-nc/4.o/), which permits non-commercial re-use, distribution, and reproduction in any medium, provided the original work is properly cited. For citation use the DOI. For commercial re-use, please contact editor@rupkatha.com. 
who belongs and who does not" to reply when Butler quotes George W. Bush, "No, the national anthem can only be sung in English" by meaning that "it's not sung in English, and it's already out of his control" (Butler, Spivak, 2010: 59-60). Very recently the present Home Minister of India also declared to have one language that is the Hindi language as global identity. Again, very interestingly in most of the South Indian states Hindi is less popular than English which was earlier regarded as traitor's language from the perspective of colonialism, though in the twenty-first century people in earlier colonized nations use English without having a sense of linguistic imperialism. But the linguistic imperialism of the English language was started to form a nation within a nation "which is an organization of people with a mechanical purpose founded on greed, jealousy, suspicion, and lust for power" (Tagore, 2012: v).

The introduction of English in India during the colonial period and its ever-growing popularity in the post-independence era reflect the hegemonic agendas of the British colonizers and the Indian elite. The 2011 Census showed English is the primary language-mother tongue-of 256 , ooo people, the second language of 83 million people, and the third language of another 46 million people, making it the second-most widely spoken language after Hindi. Sumit Sarkar in his book Modern India (1983) opines that English education which was once widely hailed as the harbinger of Renaissance is nowadays denounced as a mere instrument of alien hegemony. But ironically the Indian Renaissance or very specifically the Bengal Renaissance was experienced by a specific class, not by the mass. Most of the Renaissance figures of India were English educated and became "a class of persons, Indian in blood and colour, but English in taste, in opinions, in morals, and intellect" (Macaulay, 1946). They criticised the British rule in India, be it Keshab Chandra Sen or Dadabhai Naoroji, as the 'unbritish rule in India' including persons like Raja Rammohan Roy who degraded the Sanskritists and commented that "Hindu pundits load the minds of youth with grammatical niceties and metaphysical distinction of little or no practical use to the possessors of the society" (qt. Mukherjee, 2009: 121) and supported English education for the future development of this country, and Bankim Chandra Chattopadhyay character named Chikitsak (Physician), towards the end of the first version of Anandamath, explains to a confused Satyananda that "In order to redeem Arayadharma, it is necessary to first disseminate external related knowledge ... The English are great experts in external related knowledge, they are highly skilled in mass education. Therefore, we will make the English rulers. The people of this land having become well educated in material reality through English education, will be able to a barrier to the spread of Aryadharma. Then the true religion will shine again by itself. So long that does not happen, so long as Hindus do not again become wise, virtuous, and strong, until then English rule imperishable. Therefore, $\mathrm{O}$ wise one desisting from fighting the English, follow me". (p. 188-189; translated by Alok K Mukherjee)

It is very interesting to know that English was studied as a subject in India in 1857 though Oxford started in 1894 and Cambridge in 1911. The annual report of 1870-71 shows that a large number of English schools were established in different divisions of colonial India, as follows:

\begin{tabular}{|l|l|l|}
\hline Division & Place Name & \multicolumn{1}{|c|}{ No. Of English Schools } \\
\hline \multirow{4}{*}{ Presidency } & 24 Parganas & 49 \\
\cline { 2 - 3 } & Jessore & 47 \\
\hline \multirow{5}{*}{ Burdwan } & Midnapore & 21 \\
\cline { 2 - 3 } & Beerbhoom & 17 \\
\cline { 2 - 3 } & Burdwan & 50 (47 aided and 3 unaided) \\
\cline { 2 - 3 } & Bancoorah & 9 aided \\
\hline \multirow{2}{*}{ Rajshahye } & Moorshedabad & 24 \\
\cline { 2 - 3 } & Rajshahye & 11 \\
\hline Patna & Patna & 4 aided \\
\cline { 2 - 3 } & Shahabad & 1 unaided \\
\hline Orissa & Cuttack & 8 aided and 3 unaided \\
\hline
\end{tabular}




\begin{tabular}{|l|l|l|}
\hline \multirow{2}{*}{ Assam } & Pooree & 2 aided and 3 Anglo-vernacular \\
\cline { 2 - 3 } & Balasore & 4 Anglo-vernacular \\
\cline { 2 - 3 } & Kamroop & 4 Anglo-vernacular \\
\cline { 2 - 3 } & Nowgong & 4 Anglo-vernacular out of 32 aided \\
\hline
\end{tabular}

The division of the people of India was first started earlier by the missionaries who came to India. The first English school was established in Calcutta by the Society for Promoting Christian Knowledge in 1731. Rev. Briercliff, Bellamy, and Maploft taught in the school till Rev. Kiernander came to Calcutta on an invitation from Robert Clive. Kiernander arrived at Calcutta on $1^{\text {st }}$ December 1758 and opened another school with forty-eight scholars which swelled up to one hundred and seventy-four by the end of the year. On December 21, 1789, a public meeting was called with the Governor-General in a chair, and it was resolved that a Free School Society of Bengal would be formed to accommodate a greater number of students. Again like Mrs. Middleton from Bihar Dinapur, Bihar, William Carey advertised from Mission House, Srerampore on the $20^{\text {th }}$ March 1800 for the teaching of Greek, Hebrew, Persian, and Sanskrit and announced that particular attention would be paid to the pronunciation of English language. By the first half of the eighteenth-century English medium of education and revelation of the Gospels as the main subject of the study had become popular in the three coastal settlements such as Madras, Bombay, and Calcutta where the Englishmen dominate over the other European and also over the local Indian administration. Mr. Sherburn established a school in Calcutta which claimed Dwarakanath Tagore and Raja Rammohan Roy as its students. These missionary educators in the late eighteenth and early nineteenth century had a two-fold agenda: one, to provide basic education in English literacy and numeracy to make the pupils employable with the East India Company, the British factors, and merchants, and second, to convert them to Christianity. M. A. Laird gives a detailed account of the role that English and Scottish missionaries played in introducing English education in India. Laird notes that "an overseas extension of the English Common day Schools" where elementary English and arithmetic were taught. As Laird goes on to observe:

At first, they were ephemeral and not of a high standard; but Towards the end of the eighteenth century a few father more Ambitious schools appeared, again reflecting contemporary English educational trends. . . The best was probably the Dharmatala Academy, conducted during the second and third decades of the nineteenth century by the Scottish David Drummond; he introduced English literature and grammar, "the use of globes", Latin, and book-keeping, and his pupils Demonstrated their prowess in annual public examinations. These "mushroom schools" were intended primarily for British and Eurasian children, but in them, some Indians also Learnt the smattering of English that was necessary to qualify them for jobs in government and commercial offices, and as agents for business transactions with the British. The great majority of such men had nothing more than such a limited, practical end in view, but it was in schools of this kind also that Radha Kanta Deb, Ram Kamal Sen, Prasanna, and Dwarkanath Tagore, and others who were destined to use English for a Wider purpose received their elementary education around the Turn of the century. (Laird, 1972)

The efforts of Charles Grant and his fellow evangelicals laid the groundwork for the introduction of English education in India. In his Observations on the State of Society among the Asiatic Subjects of Great Britain, Particularly with Respect to Morals; and on the Means of Improving it he observed that

We proceed then to observe that it is perfectly in the power of this country, by degrees, to impart to the Hindoos our language; afterward through that medium, to make them acquainted with our easy literary compositions, upon a variety of subjects; and, let not the ideas hastily excite derision, progressively with the simple elements of our arts, our 
philosophy, and religion. These acquisitions would silently undermine, and at length subvert the fabric of error; all the objections that may be apprehended against such a change, are it is confidently believed, capable of a solid answer. (Grant, 1813: 77)

To prove the superiority of teaching in English he said, "Thus superior in point of advantage does the employment of English language appear and upon this ground, we have a preference to that mode proposing here, that the communication of our knowledge shall be made by the medium of our language." Again to justify the introduction of English, he wrote,

It would be extremely easy for Government to establish at a moderate expense, in various parts of the provinces, place of gratuitous instruction in reading and writing English: multitudes, especially of the young, would flock to them. . The introduction of English in the administration of revenue, in judicial proceedings, and in other business of Government wherein Persian is now used, and the establishment of free schools for instruction in this language would ensure its diffusion over the country. . . that the interest of the natives would induce them to acquire it. (Nurullah, Naik, 1971: 44)

His suggestion of English education was adopted by William Bentinck about forty years later on the advocacy of Macaulay. After describing in great detail the bad educational condition of the Indian society, he believed strongly that the introduction of the English language into India would gradually help to spread the knowledge of Christianity among the Indian people. The introduction of English education, he suggested,

would silently undermine, and at length subvert the fabric of error, and the ultimate idolatry with all ... its false principles and corrupt practices ... its ridiculous ceremonies and degrading superstitions, its lying legend, and fraudulent impositions would fall. The reasonable service of the only and infinitely perfect God would be established. (Syed, 1895: 114)

Depending on the introduction of English education two imagined communities were formedthe Orientalists and the Anglicists. The Anglicists advocated English as the substance of instruction. To Thomas Babington Macaulay, an Anglicist, English education would create a class of people "Indian in blood and colour but English in tastes, in opinions, in morals, and in intellect." In 1836, he wrote, "It is my firm belief that if our plains of education are followed up there will not be a single idolator among the respectable classes in Bengal thirty years later" (qt. Mukerji, 1966: 78). But the Orientalists' view was one of synthesis between Western and Eastern culture- "a union of Hindu and European Science and Literature on the carefully tended tree of Indian culture", as commented by Arthur Mayhew (qt. Bhattacharya, 1963: 4). One of the most notable Orientalists was Warren Hastings. Governor Hastings (1772-85) had respect for Indian traditions and culture, hence he encouraged oriental learning. They argued that the Indians may not learn the sciences through European languages as they are biased against it and hence the medium of instruction should be the classical languages of India.

The Anglicists aspired the epistemological framework of describing the native Indians as the "other", with their culture being demonized as inhuman, barbaric, uncivil, irrational, and the necessity of imposition of the superior, scientific, and civilized culture of the English on them. Thomas Babington Macaulay, an Anglicist, recommended that English education would be enterprise the colonialism of Britain. According to him, "We must at present do our best to form a class who may be interpreters between us and the millions whom we govern; a class of persons Indian in blood and colour but English in tastes, in opinions, in morals, and intellect. To that class, we may leave it to refine the vernacular dialects of the country to form the Western nomenclature, and to render them by degrees fit vehicles for conveying knowledge to the great menas of the population" (Macaulay, 1965: 116). 
In India, the choice of English education over education through the local 'vernaculars' was motivated, on one hand, by the need of 'linguistic imperialism' representing the economic interests of the Company's owners to create a comprador class, and, on the Other hand, by the plans of the Hindu elite to prepare itself to become the dominant group of the future. The early curriculum of English is another arena where the British writers were included and the native Indian writers were excluded. A glimpse of the curricula of English and vernacular of a number of institutions in the 1840s, as noted by Bhgaban Prasad Majumder in his book First Fruits of English Education [1817-1857] (1973), reveal that teaching is useful knowledge as proposed by Roy appears to have been combined with training in "our arts and our morals" advocated by Macaulay:

\begin{tabular}{|c|c|}
\hline \multicolumn{2}{|r|}{ The Curriculum of Hindu College, Calcutta, 1847} \\
\hline $\begin{array}{l}\text { English } \\
\text { Literature }\end{array}$ & $\begin{array}{l}\text { Richardson's Selections, Shakespeare, Bacon's Advancement of Learning, } \\
\text { Bacon's Novum Organum, Milton's Poetical Works, Addison's Essays, } \\
\text { Johnson's Rambler and Rasselas, Goldsmith's Essays, Hallam's Introduction to } \\
\text { the Literature of Europe in the Fifteenth, Sixteenth and Seventeenth Centuries, } \\
\text { Campbell's Rhetoric, Schlegel's History of Literature. }\end{array}$ \\
\hline $\begin{array}{l}\text { Bengali } \\
\text { Literature }\end{array}$ & Gyanapradip and Anandamangal, Digdurshan, \\
\hline \multicolumn{2}{|r|}{ The Curriculum of Free Church Institution, Calcutta, 1841} \\
\hline $\begin{array}{l}\text { English } \\
\text { Literature }\end{array}$ & $\begin{array}{l}\text { History of England, Cowper's Poems, the first book of The Task, English } \\
\text { Composition, Milton's Paradise Lost, Pollock's Course of Time, Thomson's } \\
\text { Seasons, and Castle of Indolence, Selections from Southey, Montgomery, } \\
\text { Campbell, and Wordsworth, Hallam's Introduction to the Literature of Europe } \\
\text { in the Fifteenth, Sixteenth and Seventeenth Centuries, Young's Night Thoghts, } \\
\text { Akenside's Pleasure of Imagination, Macaulay's Lays of Ancient Rome. } \\
\text { Forster's Essays in a Series of Letters. }\end{array}$ \\
\hline $\begin{array}{l}\text { Bengali } \\
\text { Literature }\end{array}$ & Hitopodesh, Madhab Chandra's Grammar. \\
\hline
\end{tabular}

An enlightening account of the teaching that took place comes from the description of the Proficient's Degree' in the Second Report of the Select Committee of the House of Lords of 1853, an advanced course of study offered by Madras University:

An acquaintance with the histories of Rome and Greece, through Goldsmith, and the histories published by the Society for the Diffusion of Useful Knowledge, and with the help of Niebuhr; the history of Modern Europe, through Russell; the history of India, through Symonds, Norton, and Marshman; and the Philosophy of History, through Smyth's Lectures. In Natural Philosophy, Plane Astronomy, through Herschell, Optics from the work of the Society for the Diffusion of Useful Knowledge, and from notes and formulae of the headmaster. Mr.Powell. Mechanics, Hydrostatics, and Pneumatics from the same materials, Chemistry from Mrs. Marcet's work. The elements of Political Economy from Mrs. Marcet's work. Mental Philosophy from Abercrombie's work. In Mathematics, Plane and Spherical Trigonometry, the first three sections of Newton's Principia, as modelled by the headmaster, and the Ellipse in Conic Sections. Reading in Shakespeare, Milton, Pope, and extracts from various authors, published in Chambers 
Encyclopedia of Literature and the Calcutta Reader; besides English composition. (Majumdar 1973)

In this way, the higher-class English educated Indians have created one English nation within the Hindustan. Vijay Agnew in her autobiography, Where I Come From, and Madhu Kishor in her article "The Dominance of Angreziyat in Our Education" have accused English education of making them unaware and ignorant of the Indian culture and writings. Vijay Agnew, in her autobiography, opines that her English education in India was responsible for her lack of academic knowledge of different practices as the Hindu caste system. She emphasizes that "my education had effectively cut me off from Indian culture."

I was a product of what we'd now call a "colonial education". It all but ignored discussion of the various regional cultures, Social organizations, and religions, such as Hinduism and Islam. I attended, like other children from privileged families, What we called in India a "convent school", in my case a school Run by Irish Catholic missionaries. The curriculum in the School did not include anything in India. We studied European history and English literature along with the other School subjects such as mathematics and biology. I remember we read Shakespeare, Charles Dickens, and Thomas Hardy, but we were not assigned any readings by Indian authors, and none of the books we read had Indian themes. I memorized the gospels of Matthew, Mark, Luke, and John, but nothing of the Ramayana or the Mahabharata, the classic Hindu religious epics... I had heard stories from, the epics at home, but had read few Indian authors, not even Tagore or Narayan Although I spoke several Indian languages, I could read And write only a little Hindi, All of my education had been in English, which Salman Rushdie calls the "bastard child of India sired on India by the departing British (2003, 20-21). It echoes the words of Ngugi WaThiong'o who in his Decolonising the Mind: The Politics of Language in African Literature (1986) writes that the effect of negating our native language "is to annihilate a people's belief in their names, in their languages, in their environment, in their heritage of struggle, in their unity, in their capacities and ultimately in themselves".

\section{References}

Agnew, Vijay (2003) Where I Come From. Canada: Wilfrid Laurier University Press, 2003.

Anderson, Benedict (2015) Imagined Communities: Reflections on the Origin and Spread of Nationalism. Jaipur: Rawat Publications.

Bhattacharya, Bijay (1963) Bengal Renaissance: A Study in the Progress of English Education 1800-1858. Calcutta, P.Sen.

Breckenridge, Carol A., Peter van der Veer, eds ((1993)) Orientalism and the Postcolonial Predicament. University of Pennsylvania Press.

Butler, Judith, Gayatri Chakravorty Spivak. (2010) Who Sings the Nation-State?: Language, Politics, Belonging. Seagull Books.

Chatterjee, Kalyan. K (1976) English Education in India: Issues and Opinions. Macmillan Publishers Ltd.

Collet, Sophia Dobson. (1914) The Life and Letters of Raja Rammohan Roy, Calcutta: Forgotten Books.

Crystal, D (2003) English as a Global Language. Cambridge University Press.

Daniel, Rachael K. English Language in India. Gyan Publishing House, 2019.

Dobson, Sophia ed (1914) The life and letters of Raja Rammohun Roy. Calcutta: Forgotten Books.

Gramsci, Antonio, Quintin Hoare, Geoffrey Nowell Smith, eds (1971) Selections from the Prison Notebooks. New York: International Publishers Co. 
7 A Nation within a Nation: English Education as a Tool of Divide and Rule Policy in Colonial India

Grant, Charles (1999) Observations on the State of Society among the Asiatic Subjects of Great Britain, Particularly with Respect to Morals. Written Chiefly in 1792. In The Great Indian Education Debate: Documents Relating to the Orientalist-Anglicist Controversy. Curzon Press.

Kishwar, Madhu. "The Dominance of Angreziyat in our Education". https:// mudhukishwar.sulekha.com/blog/post/2003/the-dominance-of-angreziyat-in-our-education.htm.

Krishnaswamy, N, Lalitha Krisnaswamy (2018) The Story of English in India. Foundation Books.

Laird, M.A. Missionaries and Education in Bengal 1793-1837 (1972) Oxford: Clarendon Press.

Macaulay, Thomas Babington (1946) Lord Macaulay's legislative minutes. Oxford University Press.

Mahmood, Sayed. (1806) A History of English Education in India, (1781 to 1893). The Honorary Secretary of the M. A. O. College, Aligarh.

Majumdar, Bhagaban Prasad (1973) First Fruits of English Education [1817-1857]. Bookland.

May, Stephen (2008) Language, and minority rights: Ethnicity, nationalism, and the politics of language. Routledge.

Mill, James (1826) The History of British India. Baldwin, Cradock, and Joy.

Moir, Martin, Lynn Zastoupil (1999) The Great Indian Education Debate: Documents Relating to the Orientalist-Anglicist Controversy, 1781-1843. Routledge.

Mukerji, Shridhar Nath (1966) History of education in India: modern period. Acharya Book Depot.

Mukherjee, Alok K (2009) The Gift of English: English Education and the Alternative Hegemonies in India. Orient Blackswan.

Nurullah, Syed, J. P. Naik (1971) A students' history of education in India, 1800-1965. Macmillan.

Ostler, N (2010) The Last Lingua Franca: English Until the Return of Babel. Penguin.

Paul, D (2012) The Cultural Politics of English as an International Language. Longman.

Paranjpe, M. R (1938) A Source Book of Modern Indian Education 1797-1902. Macmillan.

Quirk, R (2018) The Use of English. New York St. Martin's Press.

Sarkar, Sumit (1985) Modern India: 1885-1947. MacMillan India Limited.

Syed, Mahmood (1981) A History of English Education in India. Idarah-i Adabiyat-i Dellil.

Sen Gupta, Kanti Prasanna (1971) The Christian Missionaries In Bengal 1793-1833. Firma K. L. Mukhopadhyay, Calcutta.

Smith, G.E (July 1964) "Patterns of Missionary Education: The Baptist India Mission 1794-1824” Baptist Quarterly.

Tagore, Rabindranath (2012) Nationalism. New Delhi: Niyogi Books.

Thomas, Peter (2011) The Gramscian Moment: Philosophy, Hegemony, and Marxism. Haymarket Books.

Viswanathan, Gauri (1989) Masks of Conquest: Literary Study and British Rule in India. OUP.

Williams, Raymond (1983) Culture and Society: 1780-1950. Columbia University Press. 